\title{
EFEKTIFITAS MANAJEMEN SIKLUS KONVERSI KAS PERUSAHAAN SEKTOR ANEKA USAHA TERDAFTAR DI BEI
}

\author{
Gendro Wiyono \\ gw1@doctor.com \\ Universitas Sarjanawiyata Tamansiswa Yogyakarta
}

\begin{abstract}
This study aims to determine the effectiveness of cash conversion cycle management in miscellaneous industry sectors listed on the Indonesia Stock Exchange that have an impact on the financial character and price earning ratio. The sample is taken from the financial report for the period 2012-2015. Technique of collecting data using purposive sampling method with criteria: (1).Registered in Indonesia Stock Exchange 2012-2015 period; (2).The Company has financial statements has been audited by an independent auditor; (3).Company uses financial statements with rupiah currency. Data analysis to test the hypothesis using Structural Equation Modeling based on variance. The results showed that the effectiveness of cash conversion cycle management in various industry companies in Indonesia indicated by $60.20 \%$ was in minus 250 days up to 0 days. These conditions provide support for the proof of significant negative impact on corporate character and price earnings ratio. The lower the cycle period the better the financial character and the price earning ratio. However, not all corporate characters have an effect on price earning ratio. Profitability index, liquidity index, and company size index have a significant positive effect on price earnings ratio, while productivity index and dividend index have no effect on price earnings ratio.
\end{abstract}

Key words: cash conversion cycle, financial character, price earning ratio.

\begin{abstract}
ABSTRAK
Penelitian ini bertujuan untuk mengetahui efektifitas pengelolaan siklus konversi kas pada perusahaan sektor aneka industri yang berdampak pada karakter keuangan dan price earning ratio. Sampel diambil dari laporan keuangan sector aneka industri periode 2012-2015 yang terdaftar di Bursa Efek Indonesia. Teknik pengumpulan data menggunakan metode Purposive Sampling dengan kriteria: (1) Terdaftar di Bursa Efek Indonesia periode tahun 2012-2015; (2) Perusahaan mempunyai laporan keuangan yang berakhir 31 Desember dan telah diaudit oleh auditor independen; (3) Perusahaan menggunakan laporan keuangan dengan mata uang Rupiah. Analisis data untuk menguji hipotesis menggunakan Structural Equation Modeling berbasis variance. Hasil penelitian menunjukkan bahwa efektifitas pengelolaan siklus konversi kas pada perusahaan aneka industri di Indonesia terindikasi sebesar $60,20 \%$ berada pada minus 250 hari sampai dengan 0 hari. Kondisi tersebut memberikan dukungan pembuktian adanya pengaruh negatif signifikan terhadap karakter perusahaan dan price earning ratio. Semakin rendah periode siklus konversi kas semakin baik karakter keuangan dan price earning ratio. Akan tetapi tidak semua karakter perusahaan berpengaruh terhadap price earning ratio. Indeks profitabilitas, Indeks likuiditas, dan indeks ukuran perusahaan berpengaruh positip signifikan terhadap price earning ratio, sedangkan indeks produktifitas dan indeks dividen tidak berpengaruh terhadap price earning ratio.
\end{abstract}

Kata kunci: siklus konversi kas, karakter keuangan, price earning ratio.

\section{PENDAHULUAN}

Pengelolaan kas merupakan bagian dari manajemen modal kerja yang mempengaruhi pengembalian dan risiko terkait pendanaan jangka pendek serta kewajiban lancar (Ajanthan, 2013; Joseph et al., 2016;
Hoque et al., 2014). Siklus konversi kas digunakan sebagai ukuran risiko terkait pengelolaan likuiditas, yaitu waktu yang dibutuhkan dari pembelian bahan baku melalui proses produksi sampai menjadi kas kembali (Keown et al., 2003; Appuhami, 
2008). Siklus konversi kas memiliki korelasi negatif dan signifikan dengan karakter keuangan perusahaan (Al-Shubiri dan Aburumman, 2013; Alshattarat et al., 2010; Wiyono dan Mumpuni, 2016), dan price earning ratio (Wiyono dan Mumpuni, 2016; Yanti et al., 2012; Talat dan Tahir, 2012). Tidak jarang perusahaan terpaksa mengandalikan pendanaan eksternal untuk penguatan likuiditasnya sehingga perusahaan dapat mencapai kinerja yang ditargetkan (Al Nimer et al., 2013). Mengukur manajemen modal kerja dilakukan berdasarkan data aktiva lancar dan kewajiban lancar (Anagnostopoulou, 2012) yang diungkapkan melalui siklus konversi kas, dengan cara menghitung jumlah hari aktual untuk membeli bahan baku sampai dengan menjual untuk mendapatkan uang tunai (Eljelly, 2004; Al-Shuburi dan Aburumman, 2013; Dadzie dan Wiafe, 2017). Periode siklus konversi kas akan bervariasi antara satu perusahaan dengan lainnya dan dari sektor yang satu dengan sektor lainnya. Banyak peneliti yang memberikan pengertian dari sudut pandang masingmasing. Costa (2014), Wiyono dan Kusuma (2017) menyatakan bahwa Siklus Konversi Kas (Cash Conversion Cycle/CCC) merupakan ukuran bagaimana perusahaan dapat segera menerima kas melalui penjualan, yang dinyatakan dalam penjumlahan jangka waktu yang diperlukan untuk mengkonversi piutang perusahaan menjadi kas (Days Sales Outstanding/DSO) dan jangka waktu yang diperlukan untuk mengkonversi bahan baku menjadi barang jadi dan menjualnya (Days Inventory Outstanding/DIO) dikurangi dengan jangka waktu rata-rata sejak pembelian bahan baku dan penggunaan tenaga kerja hingga terlaksananya pembayaran (Days Payable Outstanding/DPO). Dengan demikian apabila dirumuskan secara sederhana dapat ditulis, $\mathrm{CCC}=\mathrm{DSO}+\mathrm{DIO}-\mathrm{DPO}$

Menurut Al-Shuburi dan Aburumman, (2013), Tauringana dan Afrifa (2013), siklus konversi kas merupakan ukuran penting bagi operasi perusahaan dimana siklu bekerja dari bahan mentah untuk diproduksi sehingga menjadi barang dan jasa yang siap dijual kepada konsumen. Oleh karena itu aliran sumber keuangan perusahaan sangat penting bagi rantai persediaan yang menjadi perhatian utama. Ide tentang siklus konversi kas pertama kali dicetuskan oleh Richards dan Laughlin (1980) sebagai teknik powerful untuk mengukur seberapa baik perusahaan mengelola modal kerjanya. Disamping berpengaruh terhadap karakter keuangan perusahaan, efektifitas pengelolaan siklus konversi kas juga berpengaruh terhadap price earning ratio (Deloof, 2003; Raheman dan Nasr, 2007). Semakin pendek siklus koversi kas, semakin bagus pengaruhnya terhadap karakter keuangan maupun price earning ratio. Karakter keuangan yang dimaksudkan adalah: indeks produktifitas, indeks profitabilitas (Nijam, 2016; Martha dan Januarti, 2013; Karaduman et al., 2011; Khan dan Ali, 2016; Ibe, 2013), indeks likuiditas (Ware, 2015; Lyroudi dan Lazaridis, 2000) indeks ukuran perusahaan, dan indeks dividen (Keown et al., 2003; Gill et al., 2010; Nobanee et al., 2011; Hashemijoo et al., 2012; Wiyono dan Mumpuni, 2016). Sementara itu Price Earning Ratio (PER) adalah rasio yang menggambarkan keuntungan emiten saham (company's earnings) terhadap harga sahamnya (stock price) Geetha dan Swaaminathan (2014), Ozlen (2014). Perhitungan PER dilakukan dengan cara membagi harga saham saat ini (current price of the stock) dengan keuntungan tahunan per saham (annual earnings per share).

Menurut Costa (2014) pengelolaan likuiditas terkait dengan kewajiban, memainkan peran penting dalam kesuksesan manajemen keuangan, dimana jika perusahaan tidak bisa mengelola posisinya dalam hal likuiditas maka tidak akan bisa membayar kewajiban lancar. Banyak Perusahaan mengandalkan dana eksternal, yang dapat saja akan berisiko menghadapi masalah pelunasan dalam jangka pendek, apalagi jika perusahaan itu tidak memiliki kemampuan keuangan yang tinggi. Raheman dan Nasr (2007); Mansoori dan Muhammad (2012); Panigrahi (2013), melaporkan hubungan yang signifikan dan negatif antara likuiditas dengan profita- 
bilitas. Teruel dan Solano (2007) menyarankan agar perusahaan menunda pembayaran untuk kinerja yang efisien. Raheman dan Nasr (2007) Menyatakan bahwa untuk performa yang lebih baik, durasi waktu untuk koleksi Piutang harus dijaga tetap pendek. Appuhami (2008), menginvestigasi hal tersebut dan menemukan bahwa arus kas operasi berpengaruh signifikan terhadap modal kerja perusahaan (Mansoori dan Muhammad, 2012). Koumanakos (2008) menyatakan bahwa semakin tinggi rata-rata persediaan yang ada di perusahaan semakin rendah tingkat pengembaliannya. Samiloglu dan Demirgunes (2008), Parveen et al. (2014) menganalisis pengaruh praktik manajemen modal kerja terhadap kinerja perusahaan, dan mereka menemukan hubungan negatif. Demikian juga dengan (Majeed et al. (2013), Lazaridis dan Tryfonidis (2006), Farah dan Oktaviani (2016) juga menganalisis hubungan antara kinerja dan manajemen modal kerja dan menemukan hubungan yang kuat antara rasio manajemen modal kerja dengan kinerja perusahaan, dan analisisnya menunjukkan hubungan yang kuat antara profitabilitas (gross operating profit) dan siklus konversi kas. Hal itu juga diperdebatkan oleh mereka bahwa manajemen siklus konversi kas yang efisien dan optimal sangat penting untuk meningkatkan kesejahteraan pemegang saham (Afza dan Nazir, 2008; Uyar, 2009; Umobong, 2015; dan Vohra et al., 2014), selain itu juga menemukan hubungan yang signifikan antara modal kerja dengan likuiditas dan profitabilitas (Shivakumar dan Thimmaiah, 2016), serta menyimpulkan bahwa ukuran perusahaan berkorelasi negatif dengan siklus konversi kas. Sementara itu, Luo et al. (2009) menyatakan bahwa jika nilai perusahaan meningkatkan siklus kas akan turun, sedangkan Christiawan dan Tarigan (2007), Gill et al., (2010) menemukan bahwa jika perusahaan mempertahankan piutang usaha, hutang dan persediaan pada tingkat optimal, maka akan menghasilkan keuntungan maksimal. Dong dan Su (2010) menemukan adanya korelasi signifikan antara siklus konversi kas dengan pengembalian investasi Perusahaan. Sharma dan Kumar (2011) menemukan bahwa di perusahaan India panjang siklus kas dan profitabilitas memiliki hubungan signifikan. Randall dan Farris (2009), Shah (2011) berpendapat bahwa dengan menerapkan cash colaboratif ke siklus manajemen kas akan mengadopsi biaya rata-rata tertimbang modal dan akan meningkatkan profitabilitas. El-Sayed Ebaid (2011) meneliti bahwa arus kas yang ada saat ini berdampak signifikan meningkatkan profitabilitas perusahaan.

Dengan demikian permasalahan yang memotivasi penelitian ini apakah siklus konversi kas berpengaruh terhadap kualitas karakter keuangan perusahaan yang diukur menggunakan indeks produktifitas, indeks profitabilitas, Indeks likuiditas, dan indeks ukuran perusahaan. Selain itu, apakah siklus konversi kas juga memiliki pengaruh terhadap nilai perusahaan yang diukur menggunakan price earning artio. Pengelolaan siklus konversi kas yang tidak efektif akan menyebabkan periode siklus tinggi sehingga karakter perusahaan tidak berkualitas. Selain itu, tentu juga akan menurunkan price earning ratio. Artinya, kemampuan memperpendek siklus konversi kas merupakan keharusan yang tidak dapat ditawar. Berdasarkan penelitian terdahulu yang telah dilakukan, maka penelitian ini bertujuan untuk menguji apakah efektifitas manajemen siklus konversi kas perusahaan sektor aneka usaha yang terdaftar di Indonesia sudah dilaksanakan secara baik sehingga meningkatkan karakter keuangan perusahaan serta price earning ratio.

\section{TINJAUAN TEORETIS \\ Siklus Konversi Kas}

Siklus konversi kas fokus pada lamanya waktu antara saat perusahaan melakukan pembayaran dan saat menerima arus kas masuk (Brigham dan Daves, 2004). Vijayakumar (2011) memberikan pengertian sebagai manajemen harian aktiva lancar dan kewajiban lancar yang dipraktekkan guna keberhasilan operasional perusahaan. Menurut Keown et al. (2003) siklus konversi kas 
adalah jumlah hari rata-rata periode pengumpulan piutang menjadi kas dan persediaan menjadi kas dikurangi periode pem bayaran rata-rata pembayaran hutang. Sementara itu Eljelly (2004) mengungkapkannya sebagai kesenjangan tunai periode waktu antara biaya untuk produksi dan penerimaan kas. Siklus konversi kas merupakan ukuran penting dalam manajemen modal kerja, yang mengukur kesenjangan antara biaya dan hasil penjualan (Padachi, 2006; Ross et al., 2003). Costa (2014) menyatakan bahwa Siklus Konversi Kas menjadi ukuran bagaimana perusahaan dapat segera menerima kas melalui penjualan, yang dinyatakan dalam penjumlahan Days Sales Outstanding (DSO) dan Days Inventory Outstanding (DIO) dikurangi dengan Days Payable Outstanding (DPO). Ross et al., (2003) menggambarkan siklus konversi kas dalam tiga tahap. Tahap pertama, fokus pada persediaan terkait mengurangi hari persediaan. Tahap kedua adalah tahap koleksi piutang dari pelanggan yang berhubungan dengan kebijakan dalam hal kecepatan pengumpulan piutang. Selain kewajiban untuk reinvestasi kas, juga untuk menyediakan likuiditas yang cukup bagi perusahaan guna melakukan operasi seharihari. Tahap ketiga adalah tahap pengelolaan hutang yang merupakan akun pembayaran kepada kreditur. Perusahaan harus menjaga kas untuk pembayaran jatuh tempo kreditor, walaupun dalam hal ini terbuka kemungkinan bagi perusahaan untuk memanfaatkan penundaan pembayaran. Faktor penentu siklus konversi kas adalah hubungan antara likuiditas yang seharusnya dipertahankan perusahaan dan kewajiban pembayaran kepada kreditur. Jika periode persediaan singkat, perusahaan dapat terkena risiko di mana ia harus mempertahankan persentase tertentu untuk memenuhi kewajibannya kepada kreditur. Disisi lain, perlu dipahami banyak debitur atau pelanggan yang menginginkan jangka waktu longgar untuk pelunasan pembayaran. Jika perusahaan menginginkan periode pembayaran dari debitur dapat diterima dalam jangka pendek, maka diperlukan kebijakan diskon dan insentif, sehingga perusahaan perlu menyeimbangkan kebijakan ini (Khan et al., 2005). Costa (2014), Wiyono dan Kusuma (2017) menyatakan bahwa Siklus Konversi Kas (Cash Conversion Cycle/CCC) merupakan ukuran bagaimana perusahaan dapat segera menerima kas melalui penjualan, yang dinyatakan dalam penjumlahan jangka waktu yang diperlukan untuk mengkonversi piutang perusahaan menjadi kas (Days Sales Outstanding/ DSO) dan jangka waktu yang diperlukan untuk mengkonversi bahan baku menjadi barang jadi dan menjualnya (Days Inventory Outstanding/DIO) dikurangi dengan jangka waktu rata-rata sejak pembelian bahan baku dan penggunaan tenaga kerja hingga pembayaran (Days Payable Outstanding/DPO).

\section{Karakter Keuangan Perusahaan}

Karakter keuangan perusahaan merupakan indikator dari kinerja keuangan perusahaan (Vintila dan Nenu, 2015). Sangat penting untuk memantau berbagai kinerja bisnis, untuk memastikan bahwa keputusan dan rencana telah dilakukan tepat waktu dan tepat sasaran. Mengingat bahwa penjualan, margin keuntungan dan arus kas adalah sumber kehidupan bisnis apa pun, pemilik harus memberi penekanan khusus pada tersedianya laporan berkala terhadap bisnis yang dilakukan. Mengetahui posisi keuangan menjadi semakin penting seiring pertumbuhan bisnis. Kurangnya pengetahuan tepat waktu mengenai posisi keuangan saat ini, dapat menyebabkan kegagalan bisnis dan memiliki konsekuensi lain bagi pemilik. Kinerja keuangan adalah ukuran subjektif dari seberapa baik perusahaan dapat menggunakan aset dari model bisnis utamanya dan menghasilkan pendapatan. Istilah ini juga digunakan sebagai ukuran umum kesehatan keuangan perusahaan secara keseluruhan selama periode waktu tertentu, dan dapat digunakan untuk membandingkan perusahaan serupa di industri yang sama atau untuk membandingkan industri atau sektor secara agregasi. Ada banyak pemangku kepentingan yang berbeda dalam perusahaan, termasuk kreditur dagang, pe- 
megang obligasi, investor, karyawan dan manajemen. Masing-masing kelompok memiliki kepentingan tersendiri dalam melacak kinerja keuangan suatu perusahaan. Analis belajar tentang kinerja keuangan dari data yang diterbitkan oleh perusahaan. Menggunakan indikator keuangan dalam pengukuran kinerja bisnis memungkinkan untuk membandingkan jenis bisnis yang berbeda. Kita dapat menentukan tujuan operasi untuk perusahaan, namun tujuan tersebut berbeda untuk perusahaan di pasar atau industri yang berbeda. Jika kita ingin membandingkan kinerja perusahaan Anda dengan beragam perusahaan lain, indikator keuangan merupakan alat netral untuk mengevaluasi kinerja. Menurut Mousa (2015) laporan keuangan perusahaan dianggap sebagai instrumen kunci yang digunakan untuk mengambil keputusan keuangan. Pernyataan keuangan memberikan informasi kunci untuk saat ini dan diantisipasi Investor, kreditur dan banyak kelompok lainnya untuk membuat keputusan rasional terkait investasi mereka, pinjaman dan portofolio. Tingkah laku terkait dengan saham atau portofolio tertentu sangat mungkin efek dari laporan keuangan. Informasi keuangan yang dikeluarkan perusahaan telah menjadi sumber penting yang menunjukkan karakter keuangan untuk setiap peserta pasar, karena ini menekan informasi asimetris antara manajer, investor, badan pengatur, masyarakat dan Stakeholder lainnya. Karena itu, salah satu pertanyaan utama yang muncul seputar kualitas pelaporan keuangan adalah pengaruhnya terhadap kinerja perusahaan berikutnya, yaitu Bagaimana kualitas nilai pasar yang dirasakan lebih tinggi ini. Perilaku manajer berpengaruh terhadap kinerja perusahaan melalui proses manajemen strategis. Dengan demikian, perlu untuk mengetahui tidak hanya tindakan manajer, keputusan dan perilaku, tapi juga strategi perusahaan dan kebijakan akuntansi, antara lain untuk menyoroti penyebab kinerja perusahaan. Kinerja perusahaan dan pertumbuhan menentukan kualitas informasi keuangan yang dilaporkan oleh perusahaan.

\section{Price Earning Ratio}

Price Earning Ratio (PER) dikenal sebagai salah satu indikator terpenting di pasar modal, yaitu rasio yang menggambarkan keuntungan emiten saham (company's earnings) terhadap harga sahamnya (stock price). Perhitungan PER dilakukan dengan cara membagi harga saham saat ini (current price of the stock) dengan keuntungan tahunan per saham (Gottwald, 2012). Menurut Wu (2014) mengutip dari Zarowin (1990), Thomas dan Zhang (2006), Wu (2013), price earning ratio telah digunakan oleh manajer keuangan untuk membentuk strategi investasi. Rasio tersebut digunakan untuk memperkirakan biaya modal ekuitas dan juga banyak digunakan oleh analis keuangan untuk membenarkan rekomendasi saham mereka. Bradshaw (2002) menemukan bahwa $76 \%$ analis sell-side mengutip price earning ratio sebagai pembenaran untuk rekomendasi saham mereka. Ini adalah variabel paling banyak digunakan melakukan analisis "Pertumbuhan" yang dikutip oleh 37\% laporan analis. Wu (2014) melanjutkan bahwa meskipun rasio ini berperan penting, namun penelitian yang ada belum sepenuhnya mengeksplorasi hubungannya dengan profitabilitas. Satu-satunya pengecualian adalah Ohlson dan Gao (2006) yang menggunakan model teoritis untuk memprediksi hubungan antara PER dan return on equity. Akan tetapi, ramalan teoritis mereka belum diuji secara empiris. Penelitian Fun dan Basana (2012) di Indonesia, investasi pada saham dengan PER rendah telah menjadi strategi investasi umum yang diikuti oleh investor. Saham dengan PER rendah memiliki harga murah saat ini sehingga diharapkan dapat menghasilkan return yang lebih tinggi pada periode berikutnya. Dengan menggunakan saham yang termasuk dalam anggota LQ 45 di Bursa Efek Indonesia temuannya menunjukkan perbedaan signifikan antara PER rendah dan PER yang tinggi dalam jangka pendek (holding period of six months) namun tidak ada perbedaan signifikan dalam jangka waktu satu sampai dengan empat tahun. Temuan ini memberi isyarat bagi investor 
untuk berinvestasi pada saham dengan PER rendah untuk jangka waktu singkat (enam bulan) guna mewujudkan profit taking, namun perlu diperhatikan bah- wa trailing lebih mendalam yang dilakukan oleh Fun dan Basana (2012) menunjukkan bahwa baik jangka pendek maupun jangka panjang investor tidak dapat memperoleh secara sistematis di atas tingkat average return dengan berinvestasi pada saham dengan PER rendah.

\section{Rerangka Pikir}

Kerangka pikir yang menjadi model penelitian digambarkan dibawah ini disusun berdasarkan teori dan penelitian yang telah dilakukan terdahulu.

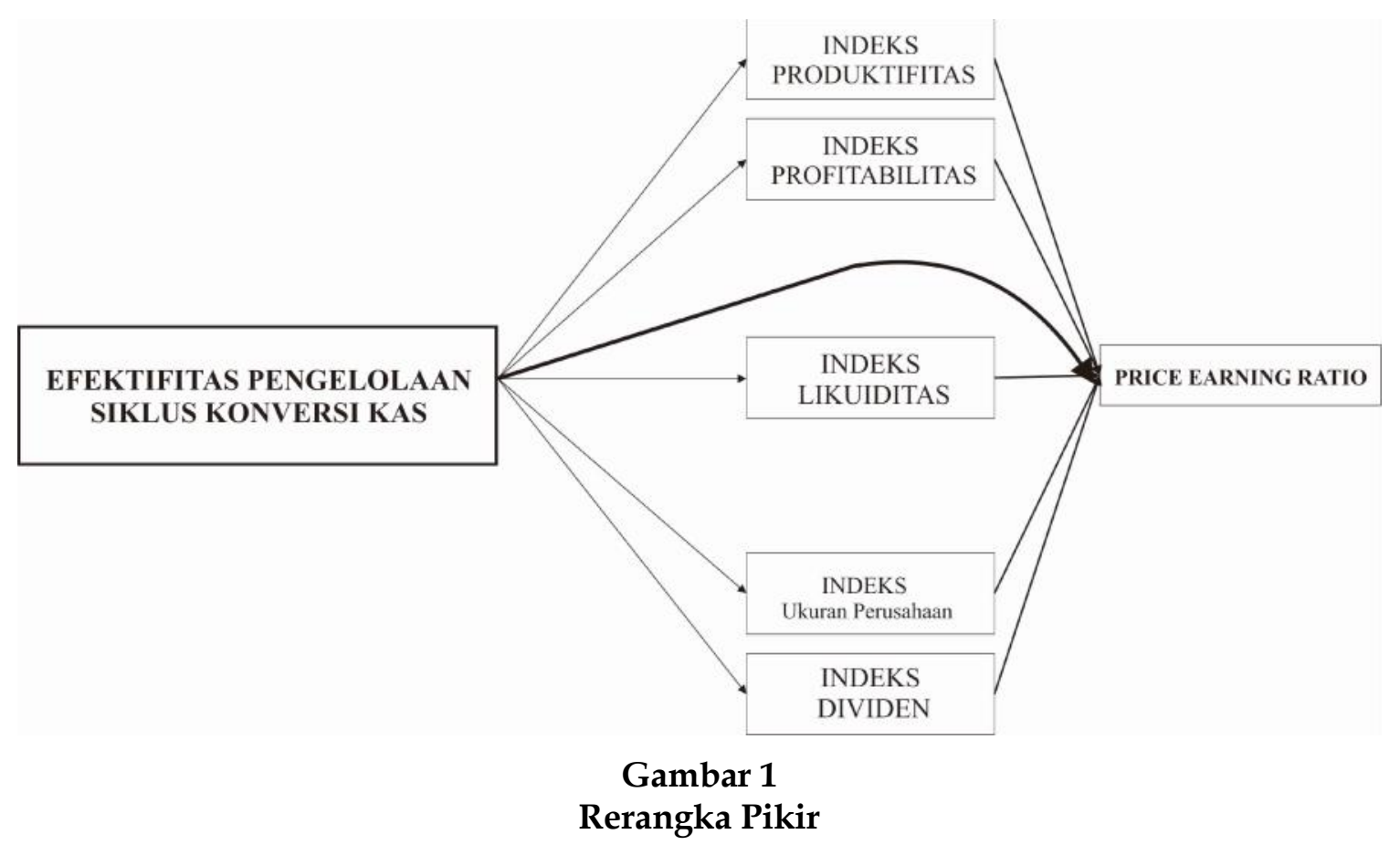

Dari gambar 1 tersebut dapat dijelaskan bahwa Kekuatan Kas yang diukur dengan Siklus Konversi Kas menunjukkan bahwa semakin pendek akan menjadi kekuatan bagi perusahaan meningkatkan kinerja karakter keuangan perusahaan. Karakter keuangan perusahaan yang direpresentasikan dengan 5 (lima) ukuran yaitu: indeks produktifitas, indeks profitabilitas, indeks likuiditas, indeks ukuran perusahaan, dan indeks dividen (Keown et al., 2003; Gill et al., 2010; Nobanee et al., 2011; Al-Shubiri dan Aburumman, 2013; Wiyono dan Mumpuni, 2016). Selanjutnya karakter keuangan yang bagus akan mendorong meningkatnya nilai perusahaan yang diukur dengan price earning ratio (Afza dan Nazir, 2008; Fun dan Basana, 2012; Wu, 2014; Ashvinkumar dan Solanki, 2014).

\section{Pengembangan hipotesis}

Berdasarkan tinjauan teoretis dan riset model di atas, selanjutnya dapat dikembangkan hipotesis berikut ini.

$\mathrm{H}_{1}$ : Siklus konversi kas berpengaruh negatif dan signifikan terhadap Indeks Produktifitas.

Berdasarkan hasil penelitian Keown et al., (2003), Gill et al. (2010), Nobanee et al., (2011), Al-Shubiri dan Aburumman (2013), dan Wiyono dan Mumpuni (2016), siklus konversi kas berpengaruh dan berhubungan negatif dengan Indeks Produktifitas.

$\mathrm{H}_{2}$ : Siklus konversi kas berpengaruh negatif dan signifikan terhadap Indeks Profitabilitas.

Berdasarkan hasil penelitian Keown et al. (2003), Gill et al. (2010), Nobanee et al., 
(2011), Al-Shubiri dan Aburumman (2013), dan Wiyono dan Mumpuni (2016), siklus konversi kas berpengaruh dan berhubungan negatif dengan Indeks Profitabilitas.

$\mathrm{H}_{3}$ : Siklus konversi kas berpengaruh negatif dan signifikan terhadap Indeks Likuiditas.

Berdasarkan hasil penelitian Keown et al. (2003), Gill et al. (2010), Nobanee et al., (2011), Al-Shubiri dan Aburumman (2013), dan Wiyono dan Mumpuni (2016), siklus konversi kas berpengaruh dan berhubungan negatif dengan Indeks Likuiditas.

$\mathrm{H}_{4}$ : Siklus konversi kas berpengaruh

negatif dan signifikan terhadap Indeks

Ukuran Perusahaan.

Berdasarkan hasil penelitian Keown et al. (2003), Gill et al. (2010), Nobanee et al., (2011), Al-Shubiri dan Aburumman (2013), dan Wiyono dan Mumpuni (2016), siklus konversi kas berpengaruh dan berhubungan negatif dengan Indeks Ukuran Perusahaan.

$\mathrm{H}_{5}$ : Siklus konversi kas berpengaruh negatif dan signifikan terhadap Indeks Dividen.

Berdasarkan hasil penelitian Keown et al. (2003), Gill et al. (2010), Nobanee et al., (2011), Al-Shubiri dan Aburumman (2013), dan Wiyono dan Mumpuni (2016), siklus konversi kas berpengaruh dan berhubungan negatif dengan Indeks Dividen.

$\mathrm{H}_{6}$ : Siklus konversi kas berpengaruh negatif dan signifikan terhadap Price Earning Ratio (PER).

Berdasarkan hasil penelitian Afza dan Nazir (2008), Fun dan Basana (2012), Wu (2014), Ashvinkumar dan Solanki (2014). Karakter keuangan yang bagus akan mendorong meningkatnya nilai perusahaan yang diukur dengan PER. Dengan demikian siklus konversi kas berpengaruh negatif terhadap PER.

$\mathrm{H}_{7}$ : Indeks Produktifitas berpengaruh positip dan signfikan terhadap PER.

Berdasarkan hasil penelitian Afza dan Nazir (2008), Fun dan Basana (2012), Wu (2014), Ashvinkumar dan Solanki (2014). Karakter keuangan yang bagus akan men- dorong meningkatnya nilai perusahaan yang diukur dengan PER. Dengan demikian Indeks Produktifitas berpengaruh positip terhadap PER.

$\mathrm{H}_{8}$ : Indeks Profitabilitas berpengaruh positip dan signfikan terhadap PER

Berdasarkan hasil penelitian Afza dan Nazir (2008), Fun dan Basana (2012), Wu (2014), Ashvinkumar dan Solanki (2014). Karakter keuangan yang bagus akan mendorong meningkatnya nilai perusahaan yang diukur dengan PER. Dengan demikian Indeks Profitabilitas berpengaruh positip terhadap PER.

$\mathrm{H}_{9}$ : Indeks Likuiditas berpengaruh positip dan signfikan terhadap PER

Berdasarkan hasil penelitian Afza dan Nazir (2008), Fun dan Basana (2012), Wu (2014), Ashvinkumar dan Solanki (2014). Karakter keuangan yang bagus akan mendorong meningkatnya nilai perusahaan yang diukur dengan PER. Dengan demikian Indeks Likuiditas berpengaruh positip terhadap PER.

$\mathrm{H}_{10}$ : Indeks Ukuran Perusahaan berpengaruh positip dan signfikan terhadap PER.

Berdasarkan hasil penelitian Afza dan Nazir (2008), Fun dan Basana (2012), Wu (2014), Ashvinkumar dan Solanki (2014). Karakter keuangan yang bagus akan mendorong meningkatnya nilai perusahaan yang diukur dengan PER. Dengan demikian Indeks Ukuran Perusahaan berpengaruh positip terhadap PER.

$\mathrm{H}_{11}$ : Indeks Dividen berpengaruh positip dan signfikan terhadap PER.

Berdasarkan hasil penelitian Afza dan Nazir (2008), Fun dan Basana (2012), Wu (2014), Ashvinkumar dan Solanki (2014). Karakter keuangan yang bagus akan mendorong meningkatnya nilai perusahaan yang diukur dengan PER. Dengan demikian Indeks Dividen berpengaruh positip terhadap PER.

\section{METODE PENELITIAN}

Penelitian ini dilakukan di Indonesia dengan mengambil sampel laporan keua- 
ngan Sektor Aneka Industri periode 20122015 yang terdaftar di Bursa Efek Indonesia. Teknik pengumpulan data menggunakan metode Purposive Sampling dengan kriteria: (1) Terdaftar di Bursa Efek Indonesia periode tahun 2012-2015; (2) Perusahaan mempunyai laporan keuangan yang berakhir 31 Desember dan telah diaudit oleh auditor independen; (3) Perusahaan menggunakan laporan keuangan dengan mata uang Rupiah. Analisis data penelitian ini menggunakan structural equation modeling berbasis variance (partial least square) dengan bantuan Software SmartPLS (Wiyono, 2011) Adapun variabel yang digunakan seperti nampak pada tabel 1 dibawah ini.

Tabel 1

Definisi Operasional Variabel

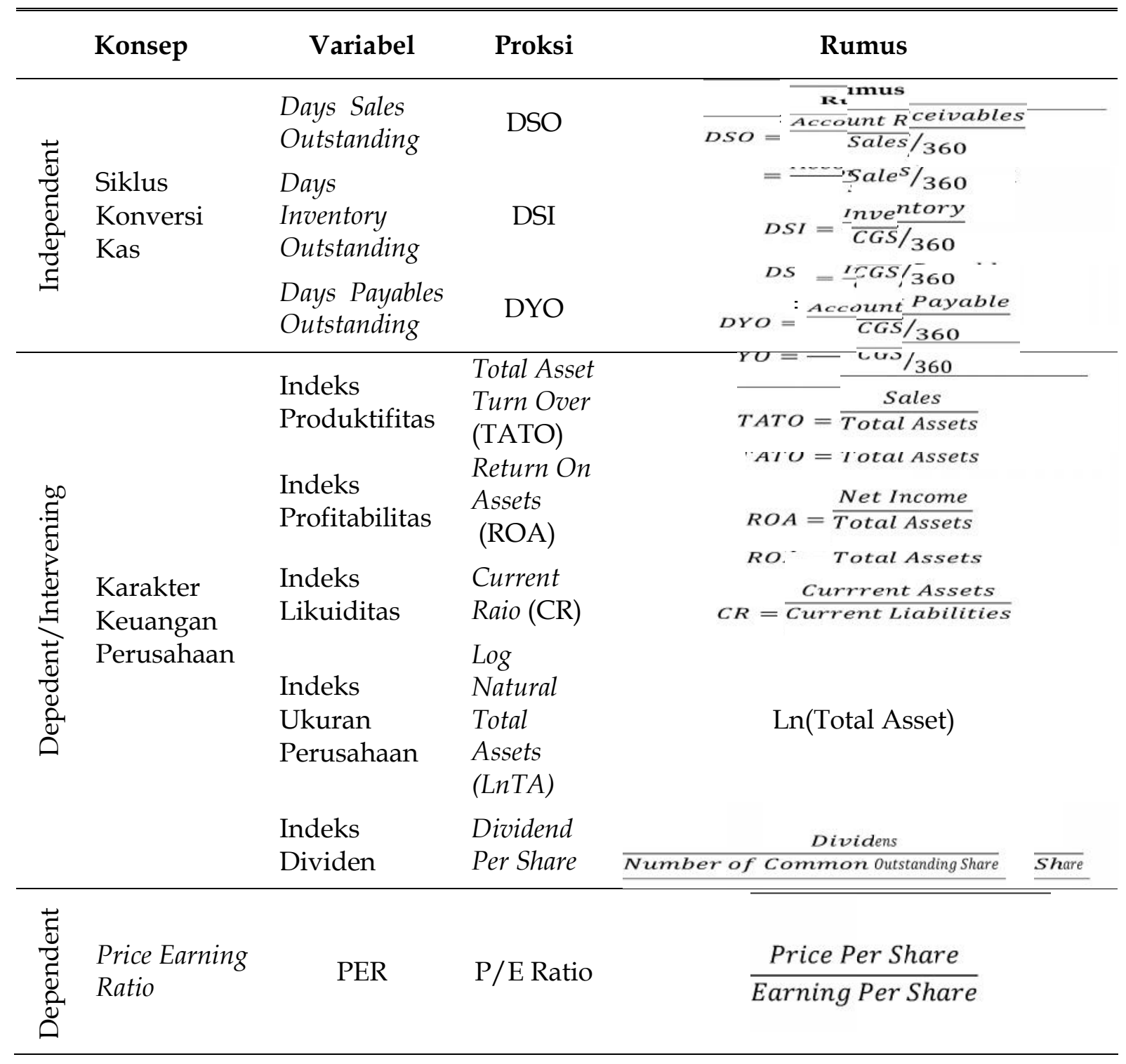

\section{ANALISIS DAN PEMBAHASAN}

Hasil penelitian menunjukkan deskripsi data secara visual masing-masing variabel seperti pada gambar 2 serta proporsi dari setiap data seperti dibawah ini.

\section{Periode Siklus Konversi Kas}

Grafik periode siklus konversi kas (diukur dengan satuan hari) serta proporsi variansinya dapat dilihat pada gambar 2 . Dari visualisasi grafik tersebut dapat dilihat 
bahwa siklus konversi kas menunjukan variansi yang beragam. Terlihat sebagian berada dibawah 0 hari dan sebagian lagi berada diatas 0 hari. Penjelasan lebih lanjut periode siklus konversi kas pada tabel 2 .

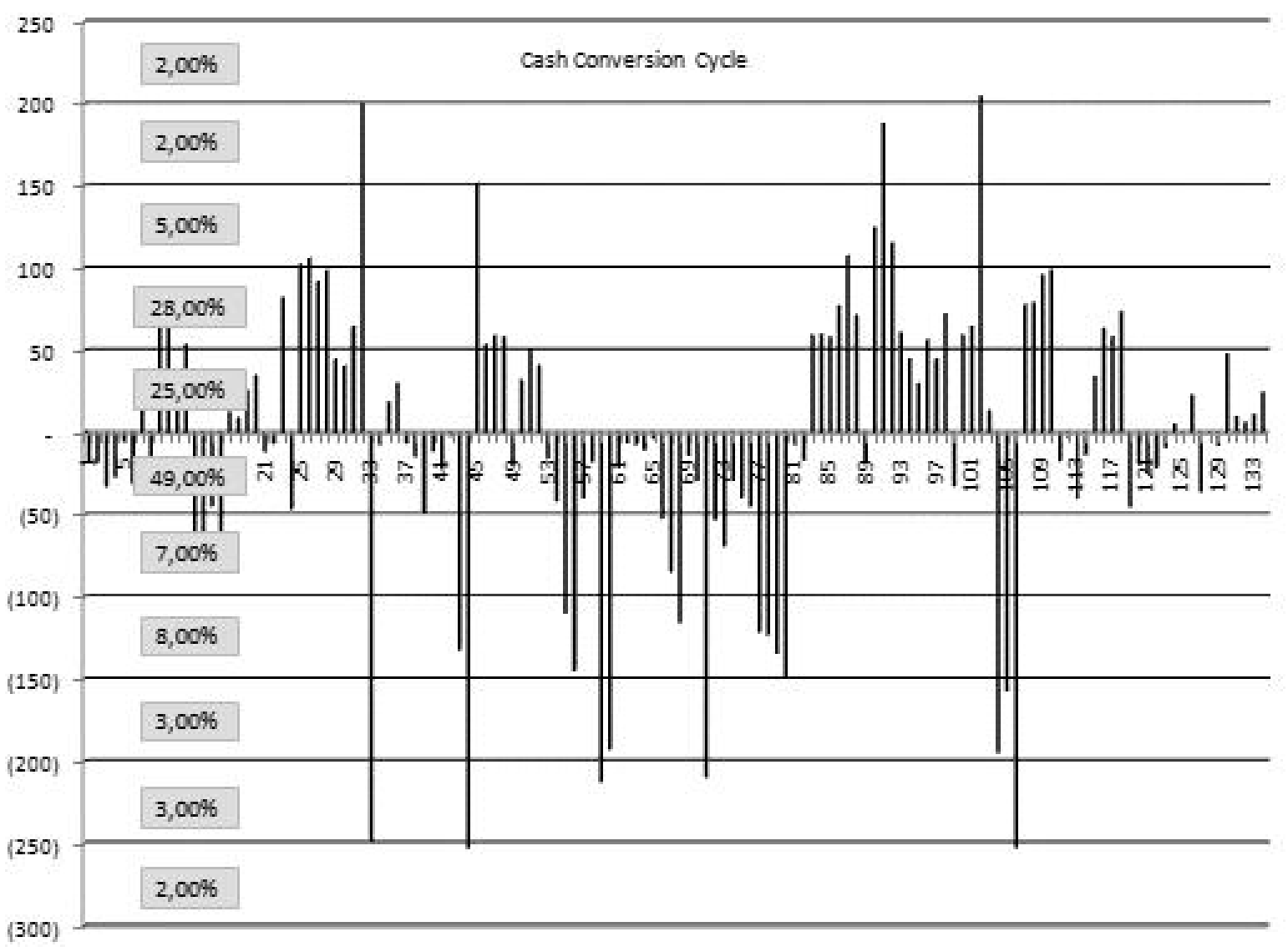

Gambar 2

Periode Siklus Konversi Kas

Tabel 2

Proporsi Periode Siklus Konversi Kas

\begin{tabular}{ccc}
\hline \hline & Range & $\begin{array}{c}\text { Proporsi } \\
\mathbf{( \% )}\end{array}$ \\
\hline & $(250)-0$ & 60,20 \\
$>$ & $0-50$ & 17,35 \\
$>$ & $50-100$ & 17,35 \\
$>$ & $100-200$ & 5,10 \\
\hline & Total & 100,00 \\
\hline
\end{tabular}

Sumber : Data Diolah

Berdasarkan tabel 2 diatas, sebesar $60,20 \%$ menunjukkan periode minus 250 sampai dengan 0 hari. Artinya, bahwa perusahaan sektor aneka usaha yang terdaftar di Bursa Efek Indonesia banyak yang telah mampu melaksanakan secara efektif manajemen siklus konversi kas. Kemampuan ini mengindikasikan bahwa perusahaan mampu mendorong periode siklus konversi kas masuk lebih cepat dari siklus kas keluar. Sebagaimana dinyatakan oleh Costa (2014), Wiyono dan Kusuma (2017), Benardi dan Bakara (2012), Majanga (2015), bahwa Siklus Konversi Kas (Cash Conversion Cycle/CCC) merupakan ukuran bagaimana perusahaan dapat segera menerima kas melalui penjualan, yang dinyatakan dalam penjumlahan jangka waktu yang diperlukan untuk mengkonversi piutang perusahaan menjadi kas (Days Sales Outstanding/DSO) dan jangka waktu yang diperlukan untuk mengkonversi ba- han baku menjadi barang jadi dan menjualnya (Days Inventory Outstanding/DIO) dikurangi dengan jangka waktu rata-rata sejak pembelian bahan baku dan peng- 
gunaan tenaga kerja hingga terlaksananya pembayaran (Days Payable Outstanding/ $D P O)$, yang dirumuskan secara sederhana: $\mathrm{CCC}=\mathrm{DSO}+\mathrm{DIO}-\mathrm{DPO}$.

\section{Indeks Produktifitas}

Grafik indeks produktifitas (diukur dengan satuan kelipatan) serta proporsi variansinya dapat dilihat pada gambar 3.

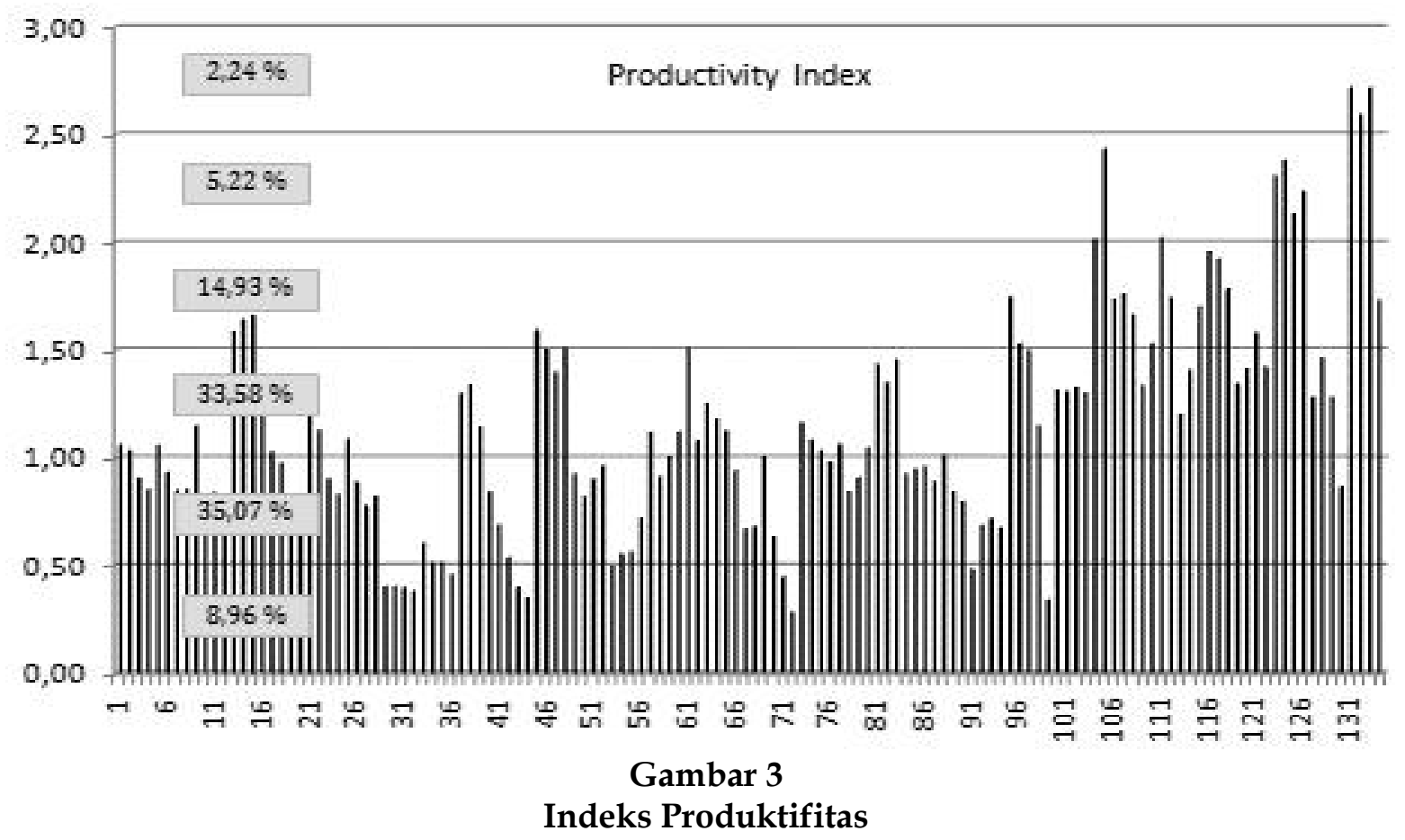

Dari visualisasi gambar 3 tersebut di atas dapat dilihat bahwa indeks produkti fitas menunjukan variansi yang beragam, namun semuanya berada diatas nilai 0 . Penjelasan lebih lanjut pada tabel 3 dibawah ini.

Tabel 3

Indeks Produktivitas

\begin{tabular}{ccc}
\hline \hline & Range & $\begin{array}{c}\text { Proporsi } \\
\mathbf{( \% )}\end{array}$ \\
\hline & $0-1$ & 33,67 \\
$>$ & $1-1,50$ & 27,55 \\
$>$ & $1,50-2,00$ & 34,69 \\
$>$ & 2,00 & 4,08 \\
& Total & 100,00 \\
\hline
\end{tabular}

Sumber : Data Diolah

Berdasarkan tabel 3, indeks produktifitas bernilai 0 sampai dengan 1 mencapai $33,67 \%$. Selebihnya bervariasi sampai de- ngan nilai diatas 2 terdapat sebesar 4,08\%. Ukuran indeks produktifitas ini menunjukkan kemampuan dana yang tertanam dalam keseluruhan aktiva berputar dalam satu periode tertentu (Gendro dan Hadri: 2017). Artinya, semakin tinggi nilai indeks produktifitas semakin bagus perusahaan mengoperasikan dan memanfaatkan aset yang dimilikinya.

\section{Indeks Profitabilitas}

Grafik indeks profitabilitas (diukur dengan satuan persentase) serta proporsi variansinya dapat dilihat gambar 4 . Dari visualisasi grafik tersebut dapat dilihat bahwa indeks profitabilitas menunjukan variansi yang beragam dengan indeks lebih banyak berada diatas nilai 0 . Penjelasan lebih lanjut pada tabel 4. Berdasarkan tabel 4, nilai indeks profitabilitas terbesar pada nilai range 1 sampai dengan 10 yaitu sebesar $44,90 \%$, selebihnya bervariasi. 


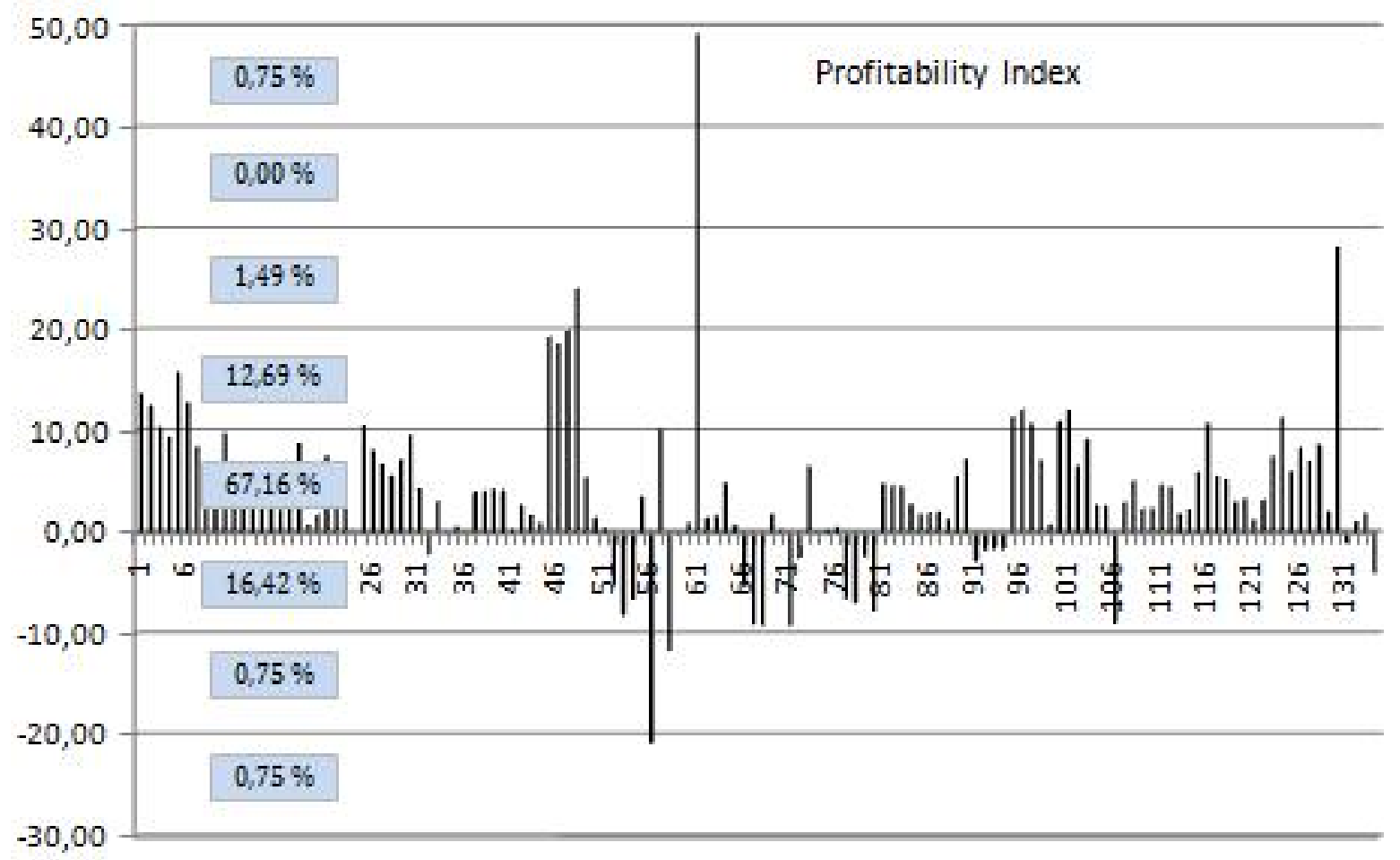

Gambar 4

Indeks Profitabilitas

Tabel 4

Indeks Profitabilitas

\begin{tabular}{ccc}
\hline \hline & Range & $\begin{array}{c}\text { Proporsi } \\
\mathbf{( \% )}\end{array}$ \\
\hline & $(11)-1$ & 24,49 \\
$>$ & $1-10$ & 44,90 \\
$>$ & $10-15$ & 15,31 \\
$>$ & $15-50$ & 10,20 \\
$>$ & 50 & 5,10 \\
\hline & Total & 100,00
\end{tabular}

Sumber : Data Diolah

Indeks tersebut diukur dengan menggunakan rumus return on assets (ROA). Rumus ini mengandung pengertian kemampuan modal yang diinvestasikan dalam keseluruhan aktiva untuk menghasilkan keuntungan bagi semua investor baik pemegang saham maupun kreditor.

\section{Indeks Likuiditas}

Grafik indeks likuiditas (diukur dengan satuan persentase) serta proporsi variansi. nya dapat dilihat pada gambar 5. Dari visualisasi grafik tersebut dapat dilihat bahwa indeks likuiditas menunjukkan variansi yang beragam (syarat mutlak harus berada diatas 0 agar perusahaan tetap beroperasi). Indeks ini diukur dengan menggunakan rumus current ratio. Penjelasan lebih lanjut pada tabel 5 .

Tabel 5

\section{Indeks Likuiditas}

\begin{tabular}{ccc}
\hline & Range & $\begin{array}{c}\text { Proporsi } \\
(\mathbf{0})\end{array}$ \\
\hline & $10-50$ & 19,39 \\
$>$ & $50-100$ & 14,29 \\
$>$ & $100-200$ & 24,49 \\
$>$ & $200-500$ & 28,57 \\
$>$ & 500 & 13,27 \\
\hline & Total & 100,00 \\
\hline
\end{tabular}

Sumber : Data Diolah

Berdasarkan tabel 5, indeks likuiditas yang paling tinggi dalam range 200\% sampai dengan $500 \%$. 


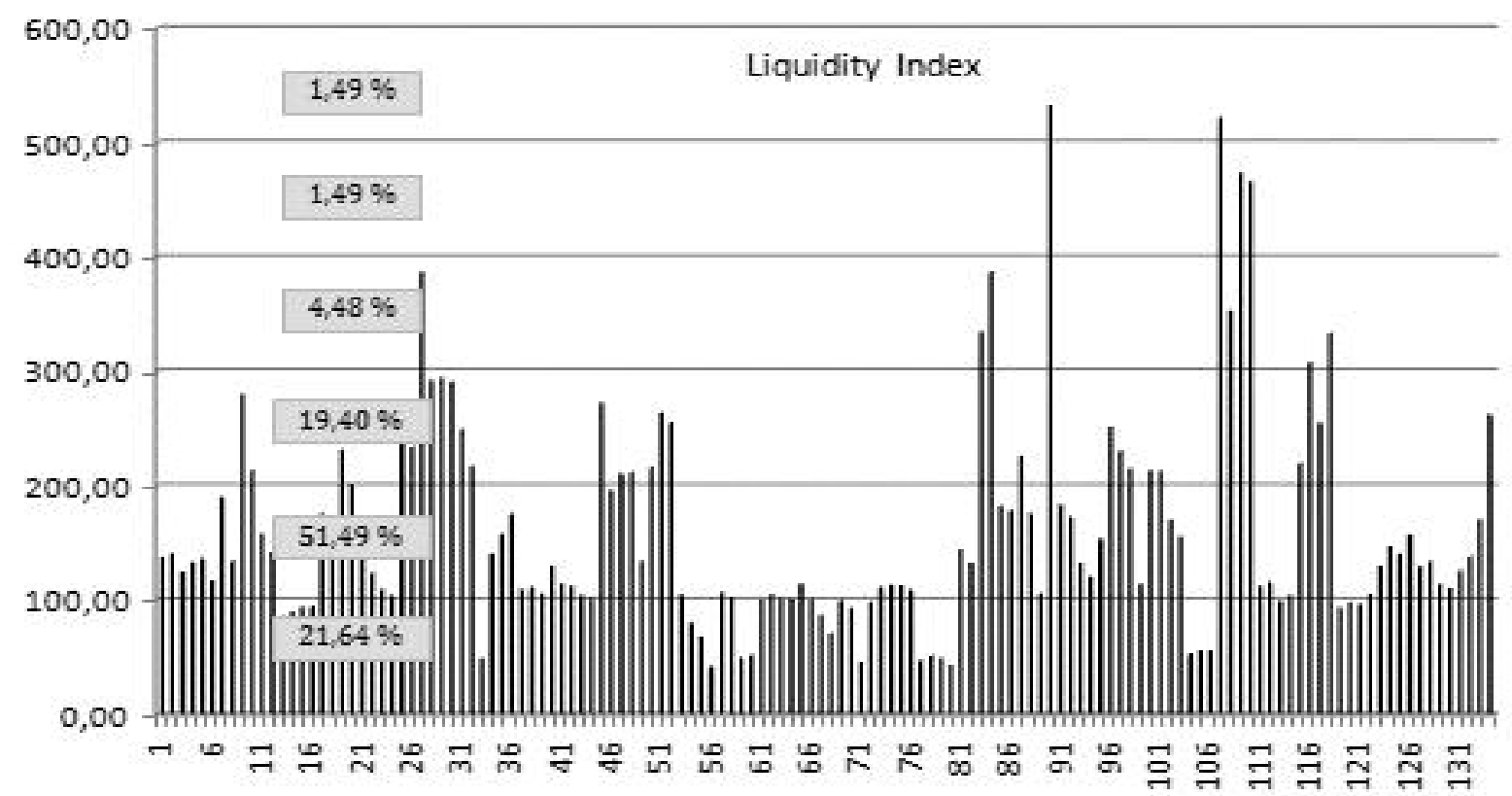

\section{Gambar 5 \\ Indeks Likuiditas}

Rumus current ratio yang digunakan untuk mengukur indeks likuiditas tersebut mengandung arti bahwa perusahaan memiliki kemampuan untuk membayar utang pendek yang segera harus diselesaikan. Dengan demikian, merujuk pada tabel-5 terdapat perusahaan sektor aneka usaha yang terdaftar pada Bursa Efek Indonesia sebesar 19,39\% memiliki kemampuan kurang yaitu hanya sebesar $10 \%$ sampai dengan 50\% untuk membayar utang jangka pendeknya.

\section{Indeks Ukuran Perusahaan}

Grafik indeks ukuran perusahaan (diukur menggunakan Log Natural dari Total Assets) serta proporsi variansinya dapat dilihat pada gambar 6 .

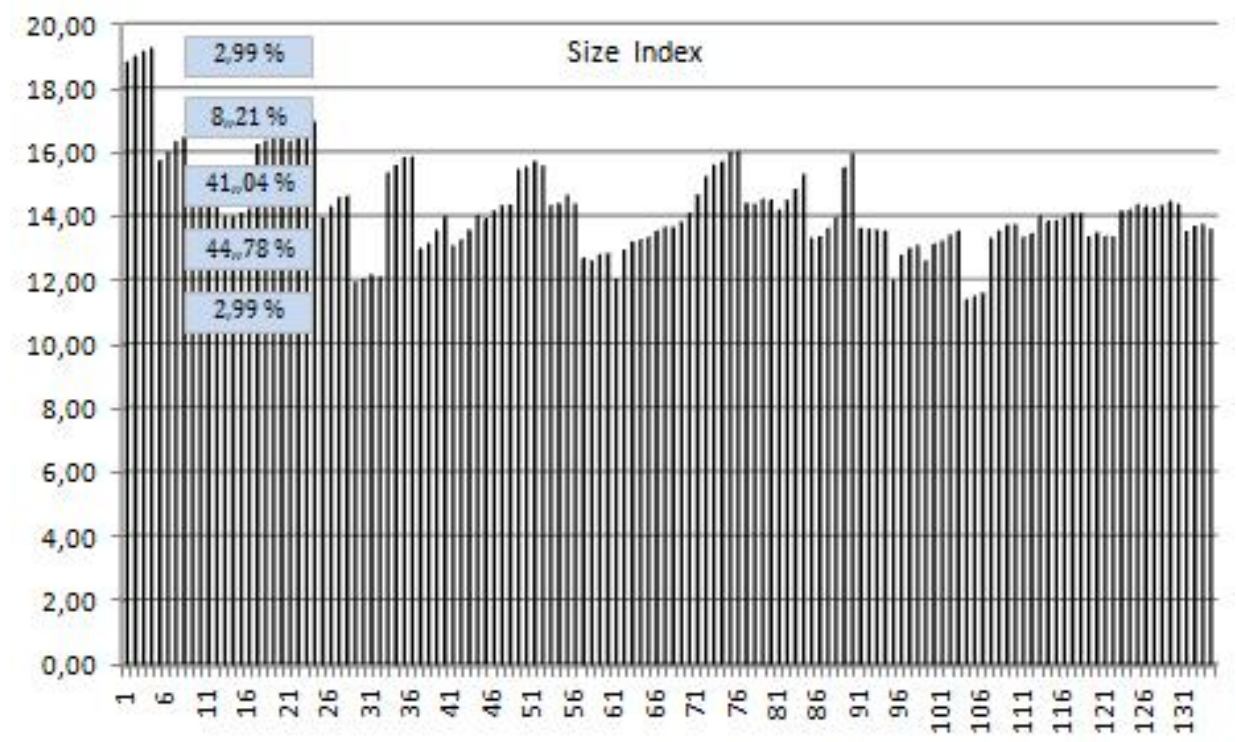

Gambar 6

Indeks Ukuran Perusahaan 
Dari visualisasi grafik tersebut diatas dapat dilihat bahwa indeks ukuran perusahaan menunjukan variansi yang beragam, walaupun nampak secara umum mendekati kesamaan. Penjelasan lebih lanjut pada tabel 6 dibawah ini.

Tabel 6

Indeks Ukuran Perusahaan

\begin{tabular}{ccc}
\hline \hline & Range & $\begin{array}{c}\text { Proporsi } \\
\mathbf{( \% )}\end{array}$ \\
\hline & $10-12$ & 11,22 \\
$>$ & $12-14$ & 28,57 \\
$>$ & $14-16$ & 40,82 \\
$>$ & $16-18$ & 15,31 \\
$>$ & $18-20$ & 4,08 \\
\hline & Total & 100,00
\end{tabular}

Sumber : Data Diolah

Berdasarkan tabl 6, ukuran perusahaan bervariasi, akan tetapi secara umum nilai indeks 14 sampai 16 mempunyai porsi tertinggi yaitu 40,82\%. Hasil penelitian Sun (2012) menunjukkan bahwa ukuran perusahaan sedikit membantu dalam memprediksi kelebihan return baik dalam jangka pendek maupun jangka panjang. Menurut penelitian ini, hal tersebut me- nyebabkan uji PER kurang terdeteksi

\section{Indeks Deviden}

Grafik indeks deviden (diukur menggunakan persentase dividend per share) serta proporsi variansinya dapat dilihat pada gambar 7. Dari visualisasi grafik pada gambar 7 tersebut dapat dilihat bahwa indeks deviden menunjukkan variansi yang rendah.

Beberapa diantaranya terlihat indeks dividen sangat tinggi, namun sebagian bernilai 0 . Penjelasan lebih lanjut pada tabel 7.

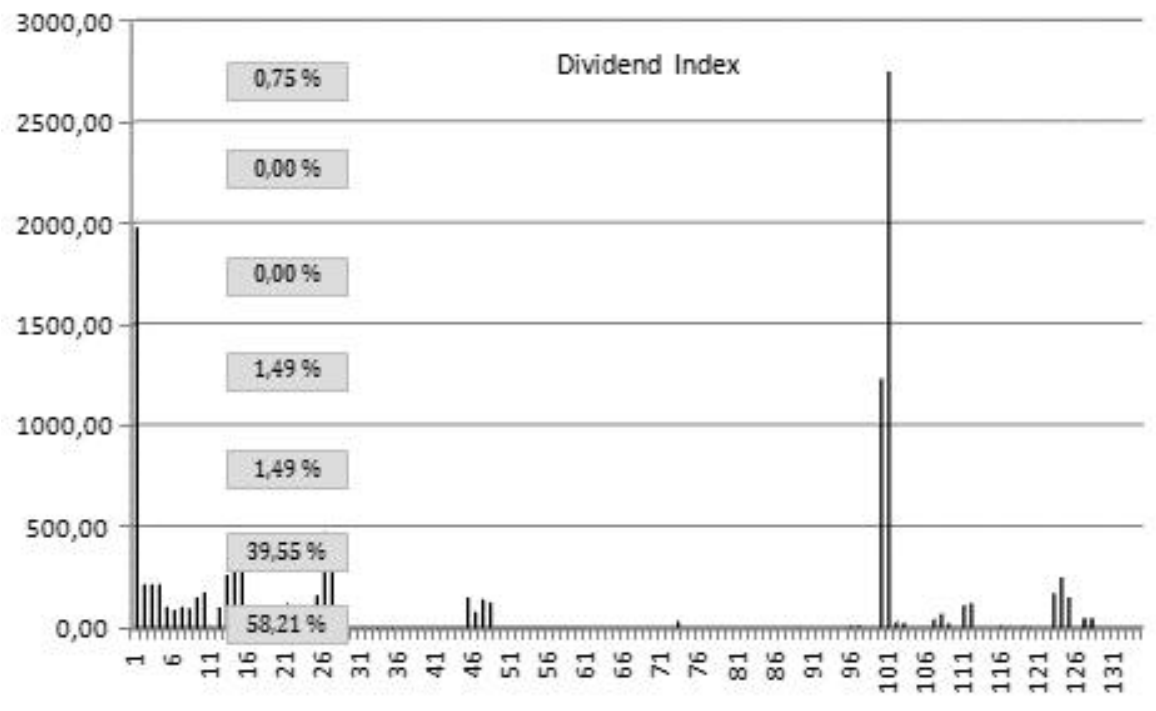

\section{Gambar 7}

Indeks Deviden

Seperti nampak pada tabel 7, indeks dividen bernilai 0 tercatat sebesar 26,53\%. Selebihnya bervariasi, akan tetapi bernilai sangat menonjol > 500 tercatat sebesar 24,49\%. Penelitian Matthew et al. (2014) yang menguji pengaruh pembayaran dividen terhadap harga pasar saham perusahaan pada Bursa Efek Nigeria (NSE). Studi ini tampaknya merupakan tes konfirmasi relevansi dividen atau ketidak relevanan seperti yang dikemukakan oleh berbagai mazhab pemikiran.

Dengan menggunakan sampel dari 17 perusahaan yang dikutip pada periode 
Tabel 7 Indeks Dividen

\begin{tabular}{ccc}
\hline \hline & Range & $\begin{array}{c}\text { Proporsi } \\
\mathbf{( \% )}\end{array}$ \\
\hline & 0 & 26,53 \\
$>$ & $1-10$ & 9,18 \\
$>$ & $10-50$ & 19,39 \\
$>$ & $50-500$ & 20,41 \\
$>$ & 500 & 24,49 \\
\hline & Total & 100,00 \\
\hline
\end{tabular}

Sumber : Data Diolah

2003 sampai 2011, studi ini memberikan bukti empiris dan statistik mengenai hubungan antara pembayaran dividen dan harga saham perusahaan. Hasilnya menunjukkan terdapat hubungan positif antara pembayaran dividen dan harga pasar. Penelitian tersebut juga memberikan bukti efek agregat dari pembayaran dividen atas harga saham. Akan tetapi hasilnya menegaskan bahwa dampak pembayaran dividen terhadap harga saham tidak signifikan sesuai dengan ketidak relevanannya teori Miller dan Modigliani (1961).

\section{Price Earning Ratio}

Grafik price earning ratio (diukur menggunakan satuean persentase) serta proporsi variansinya dapat dilihat pada gambar 8 . Dari visualisasi grafik tersebut diatas dapat dilihat bahwa price earning ratio menunjukkan variansi yang beragam, meskipun terlihat ada beberapa yang menonjol. Penjelasan lebih lanjut pada tabel 8 .

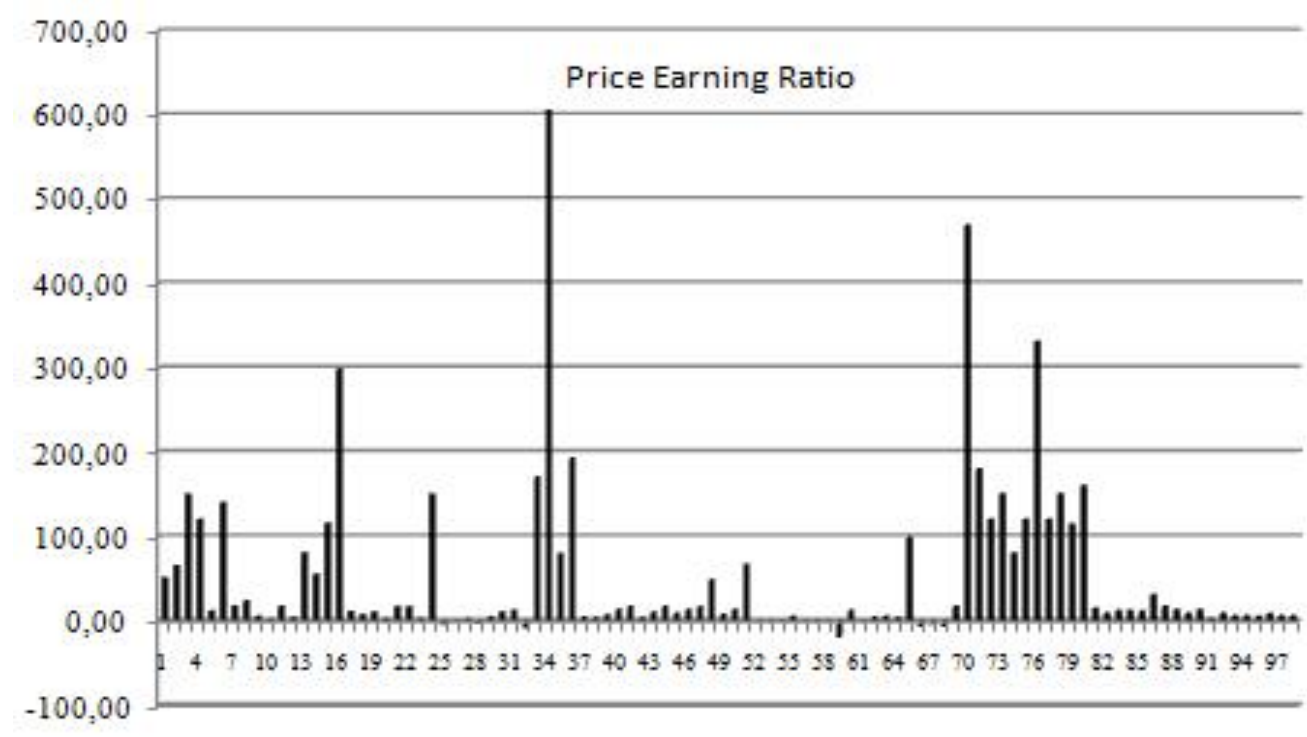

\section{Gambar 8 \\ Price Earning Ratio}

Tabel 8

Price Earning Ratio

\begin{tabular}{ccc}
\hline \hline & Range & $\begin{array}{c}\text { Proporsi } \\
(\mathbf{0})\end{array}$ \\
\hline & $(19)-0$ & 13,27 \\
\hline$>$ & $0-10$ & 33,67 \\
\hline$>$ & $10-50$ & 26,53 \\
\hline$>$ & $50-200$ & 22,45 \\
\hline$>$ & 200 & 4,08 \\
\hline & Total & 100,00 \\
\hline
\end{tabular}

Sumber : Data Diolah
Seperti terlihat pada tabel 8, porsi tetinggi adalah PER pada range $>0$ sampai dengan 10. Disamping ada yang bernilai tinggi, yang perlu dicatat adalah PER dengan nilai minus 19 sampai dengan nilai 0 terdapat sebesar $13,27 \%$. Hal ini dimungkinkan sangat terkait dengan pembayaran dividen sebagaimana hasil penelitian Matthew et al. (2014) yang menguji pengaruh pembayaran dividen terhadap harga pasar saham perusahaan pada Bursa 
Efek Nigeria (NSE) memberikan bukti empiris dan statistik adanya hubungan positif antara pembayaran dividen dan harga pasar (price earning ratio).

\section{Hasil Pengujian Hipotesis}

Hasil ouput SmartPls 3.2.6 menghasilkan gambar model dari hasil proses bootstraping seperti pada gambar 9 .

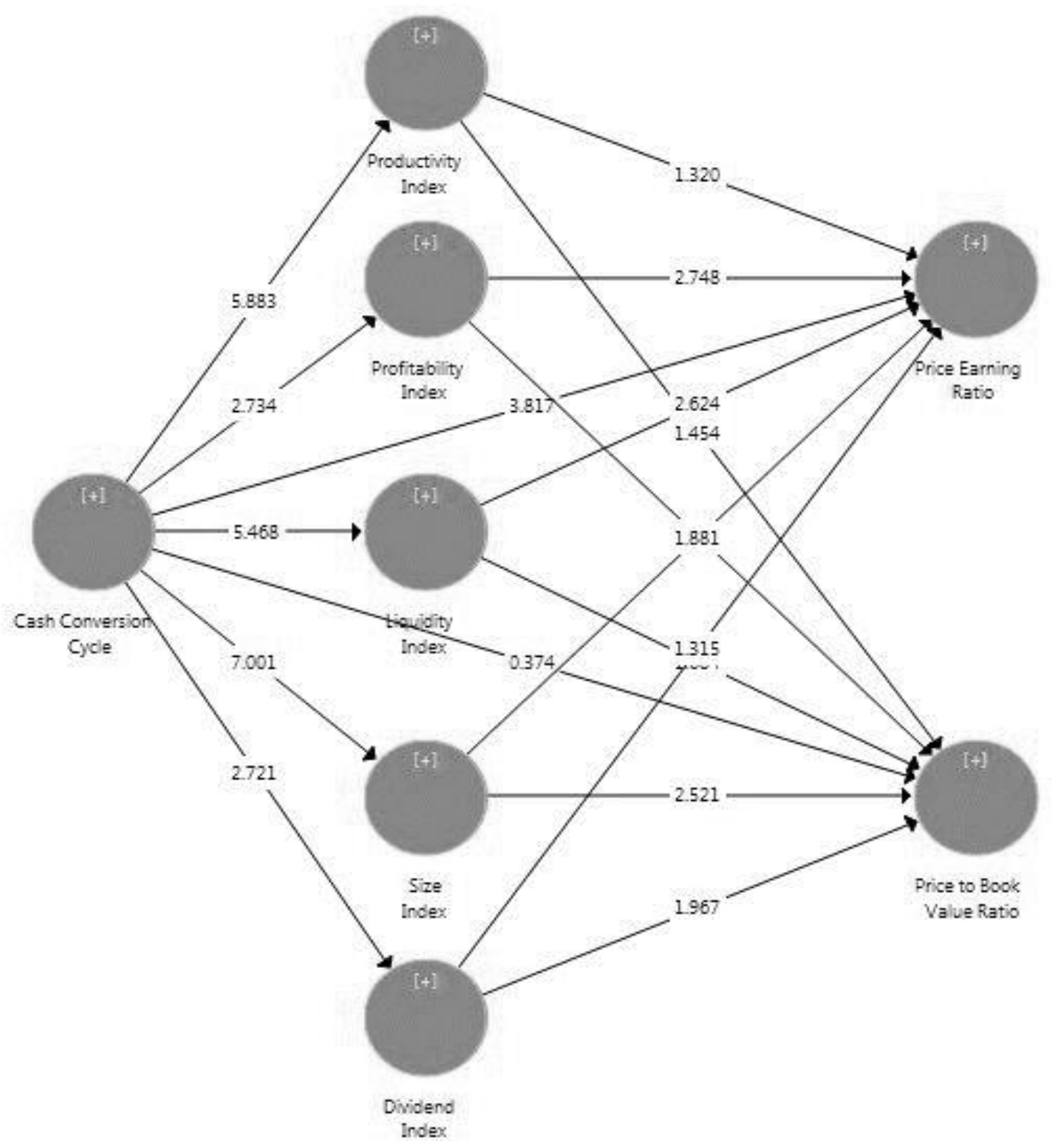

Gambar 9

Output SmartPLS

Berdasarkan output model SmartPls diatas, selanjutnya dapat dilihat hasil dari pengujian hipotesis pada tabel 9. Tabel 9 diatas menunjukkan bahwa siklus konersi kas (cash conversion cycle) terbukti berpengaruh negatif dan signifikan terhadap karakter keuangan perusahaan yang meliputi: indeks produktifitas, indeks profita- bilitas, indeks likuiditas, indeks ukuran perusahaan, dan indeks dividen. Hasil ini mendukung teori dan penelitian yang terdahulu (Al-Shubiri dan Aburumman, 2013; Wiyono dan Mumpuni, 2016).

Semakin rendah siklus konversi kas, maka semakin meningkat karakter keuangan perusahaan. 
Tabel 9

Hasil Pengujian Hipotesis

\begin{tabular}{lcccc}
\hline \multicolumn{1}{c}{ Variables } & Coeficient & Pvalues & Status \\
\hline Cash Conversion Cycle $\rightarrow$ Indeks Produktifitas. & $-0,426$ & 0,000 & Terbukti \\
Cash Conversion Cycle $\rightarrow$ Indeks Profitabilitas. & $-0,379$ & 0,006 & Terbukti \\
Cash Conversion Cycle $\rightarrow$ Indeks Likuiditas. & $-0,516$ & 0,000 & Terbukti \\
Cash Conversion Cycle $\rightarrow$ Indeks Ukuran & $-0,439$ & 0,000 & Terbukti \\
Perusahaan & & & \\
Cash Conversion Cycle $\rightarrow$ Indeks Dividen & $-0,370$ & 0,007 & Terbukti \\
Cash Conversion Cycle $\rightarrow$ Price Earning Ratio. & $-0,390$ & 0,000 & Terbukti \\
Indeks Produktifitas $\rightarrow$ Price Earning Ratio & $-0,158$ & 0,187 & Tidak Terbukti \\
Indeks Profitabilitas $\rightarrow$ Price Earning Ratio & $-0,219$ & 0,006 & Terbukti \\
Indeks Likuiditas $\rightarrow$ Price Earning Ratio & $-0,229$ & 0,009 & Terbukti \\
Indeks Ukuran Perusahaan $\rightarrow$ Price Earning Ratio & 0,216 & 0,012 & Terbukti \\
Indeks Dividen $\rightarrow$ Price Earning Ratio & 0,161 & 0,189 & Tidak Terbukti \\
\hline
\end{tabular}

Adapun terhadap price earning ratio, siklus konversi kas juga berpengaruh negatif signifikan mendukung penelitian sebelumnya yang telah dilakukan oleh Afza dan Nazir (2008), Fun dan Basana (2012), Wu (2014), Ashvinkumar dan Solanki (2014), Sementara itu pengaruh karakter perusahaan terhadap PER tidak semuanya terbukti. Indeks profitabilitas, indeks likuiditas, dan indeks ukuran perusahaan terbukti berpengaruh terhadap PER, sedangkan indeks produktifitas, dan indeks dividen tidak terbukti berpengaruh signifikan terhadap PER. Indeks produktifitas tidak berpengaruh terhadap PER karena ukuran ini secara langsung tidak menarik investor untuk menjadi daya dorong permintaan atas saham, namun penelitian yang dilakukan oleh Khotimah dan Murtaqi (2015), menyatakan bahwa total aset trunover dapat menjelaskan efisiensi pengelolaan perusahaan. Ukuran ini menujukkan kecepatan mengubah proses dari berbagai akun ke penjualan atau kas. Dengan kata lain rasio ini menunjukkan bagaimana sebuah perusahaan menggunakan Aktivanya untuk menghasilkan penjualan. Semakin tinggi rasio ini menunjukkan indikasi lebih baik, lebih tinggi rasio perputaran (turnover) artinya perusahaan menggunakan aktivanya lebih efisien.
Indeks dividen tidak berpengaruh terhadap price earning ratio, disebabkan karena sebanyak 26,53\% perusahaan tidak memberikan dividen. Menurut Van Horne (1987) dalam Jakata dan Nyamugure (2013), ketika perusahaan mengumumkan kenaikan dividen, harga dari Saham meningkat. Ketika sebuah perusahaan mengumumkan dividen yang dikurangi maka harga saham menurun. Bila dividen tetap sama, harga saham tetap. Dari semua perusahaan yang diteliti ditemukan bahwa kenaikan harga tidak begitu penting. Dengan kenaikan dividen ini menyebabkan investor mempertahankan pendapatan untuk mencapai capital gain. Teori Miller dan Modigliani (1961) mengatakan Bahwa dividen hanyalah sinyal belaka dari prospek masa depan perusahaan. Peningkatan dividen merupakan sinyal prospek untuk dividen di masa depan. Sinyal menyebabkan harga Saham untuk naik dan turun. Perubahan harga dari saham mencerminkan bahwa investor telah menerima informasi baru tentang dividen.

\section{SIMPULAN DAN SARAN}

Efektifitas pengelolaan siklus konversi kas pada perusahaan aneka industri di Indonesia terindikasi bagus, dimana sebesar $60,20 \%$ menunjukkan periode minus 250 hari 
sampai dengan 0 hari. Hal ini menunjukkan bahwa perusahaan sektor aneka usaha yang terdaftar di Bursa Efek Indonesia banyak yang mampu melaksanakan secara efektif manajemen siklus konversi kas. Kemampuan ini mengindikasikan bahwa perusahaan mampu mendorong periode siklus konversi kas masuk lebih cepat dari siklus kas keluar. Sebagaimana dinyatakan oleh Costa (2014), Wiyono dan Kusuma (2017) bahwa Siklus Konversi Kas merupakan ukuran bagaimana perusahaan dapat segera menerima kas melalui penjualan, yang dinyatakan dalam penjumlahan jangka waktu yang diperlukan untuk mengkonversi piutang perusahaan menjadi kas dan jangka waktu yang diperlukan untuk mengkonversi bahan baku menjadi barang jadi dan menjualnya dikurangi dengan jangka waktu rata-rata sejak pembelian bahan baku dan penggunaan tenaga kerja hingga terlaksananya pembayaran. Dengan kondisi seperti itu, siklus konversi kas terbukti berpengaruh negatif dan signifikan terhadap karakter perusahaan maupun terhadap PER. Akan tetapi karakter keuangan perusahaan yang berhasil dibangun oleh efektifitas manajemen siklus konversi kas tidak semuanya berpengaruh positip dan signifikan terhadap price earning ratio. Indeks Profitabilitas, Indeks Likuiditas, dan Indeks Ukuran Perusahaan berpengaruh positip dan signifikan terhadap PER, sedangkan Indeks Produktifitas, dan Indeks Dividen tidak berpengaruh terhadap PER.

Dari hasil temuan penelitian ini, direkomendasikan kepada manajemen perusahaan agar kebijakan umur piutang perusahaan menjadi perhatian. Konsep percepatan hari pengumpulan piutang perlu menjadi prioritas. Proses produksi harus terjadwal dan cepat agar tidak banyak bahan baku yang menumpuk dengan kualitas barang yang disukai konsumen sehingga cepat terjual dan menjadi kas. Utang perusahaan jangka pendek terhadap vendor harus dilakukan pengelolaan yang baik dengan mengedepankan kepercayaan (trust). Penjualan yang tinggi dengan kualitas barang dan jasa yang bagus akan mendorong timbulnya trust dari vendor, sehingga vendor tidak terlalu menekan adanya keharusan jangka waktu pembayaran utang jangka pendek. Kebijakan dividen perlu mendapat perhatian yang cukup apabila karakter investor sebagian besar cenderung menghendaki adanya pembagian dividen. Dengan rekomendasi tersebut, diharapkan periode siklus konversi kas akan pendek (akan sangat menguntungkan apabila mi nus), dan mendorong naiknya kualitas karakter keuangan perusahaan.

\section{DAFTAR PUSTAKA}

Afza, T. dan M. S. Nazir. 2008. Working Capital Approaches and Firm's Returns. Pakistan Journal of Commerce and Social Sciences 1(1): 25-36.

Ajanthan, A. 2013. Working Capital Mana gement (WCM) and Corporate Profitability (CP): A Study of Selected Listed Companies in Sri Lanka. The International Journal of Business \& Management 1(2): 10-17.

Al Nimer, M., L. Warrad, dan R. Al Omari. 2013. The Impact of Liquidity on Jordanian Banks Profitability through Return on Assets. Interdisciplinary Journal of Contemporary Research in Business 5(7): 70-76.

Al-Shubiri, F. N. dan N. M. Aburumman. 2013. The Relationship between Cash Conversion and Financial Characteristics of Industrial Sectors: an Empirical Study. Investment Management and Financial Innovations 10(4): 95-102.

Alshattarat, W. K., H. Nobanee, A. E. Haddad, dan M. Al Hajjar. 2010. Working Capital Management, Operating Cash Flow and Corporate Performance. International Journal of Strategic Management 10(1): 84-88.

Anagnostopoulou, S. C. 2012. Working Capital Management and Firm Listing Status. Multinational Finance Journal 16(3/4): 261-301.

Appuhami, B. A. R. 2008. The Impact of Firms' Capital Expenditure on Working Capital Management: An Empirical 
Study across Industries in Thailand. International Management Review 4(1): 821.

Ashvinkumar dan H. Solanki. 2014. Relationship between P/E Ratio and Stock Return" with Reference to BSE 100. Global Journal for Research Analysis 3(8): 142-145.

Benardi, B. dan M. Y. V. Bakara. 2012. Mengukur Cash Conversion Cycle Perusahaan Terbuka Operator Telekomunikasi Seluler di Indonesia dalam Keterkaitannya dengan Kinerja Pengelolaan Modal Kerja. IncomTech, Jurnal Telekomunikasi dan Komputer 3(1): 27-47.

Bradshaw, M. T. 2002. The Use of Target Prices to Justify Sell-side Analysts' Stock Recommendations. Accounting Horizons 16(1): 27-41.

Brigham, E. dan P. Daves. 2004. Intermediate Finance Management. 8th Edition. South Western. New York.

Christiawan, Y. J. dan J. Tarigan. 2007. Kepemilikan Manajerial: Kebijakan Hutang, Kinerja, dan Nilai Perusahaan. Jurnal Akuntansi dan Keuangan 9(1): 1-8.

Costa, B. R. D. 2014. Cash Conversion Cycle across Industries. A Work Project, Presented as Part of the Requirements for the Award of a Masters Degree in Management from the NOVA - School of Business and Economics.

Dadzie, E. A. dan N. A. Wiafe. 2017. Working Capital Management and Profitability of Manufacturing Firms in Ghana. Journal of Excellence, Leadership, E Stewardship 6(2): 30-42.

Deloof, M. 2003. Does Working Capital Management Affect Profitability of Belgian Firms?. Journal of Business Finance \& Accounting 30(3-4): 573-578.

Dong, H. dan J. Su. 2010. The Relationship between Working Capital Management and Profitability: a Vietnam Case. International Research Journal of Finance and Economics 49: 62-71.

El-Sayed Ebaid, I. 2011. Accruals and the Prediction of Future Cash Flows Empirical Evidence from an Emerging Market.
Management Research Review 34(7): 838853.

Eljelly, A. M. 2004. Liquidity-Profitability Tradeoff: an Empirical Investigation in an Emerging Market. International Journal of Commerce and Management 14(2): 48-61.

Farah, M. dan C. Oktaviani. 2016. Pengaruh Manajemen Modal Kerja terhadap Profitabilitas pada Usaha kecil dan Menengah di Indonesia. Jurnal Bisnis dan Akuntansi 18(1): 11-24.

Fun, L. P. dan S. R. Basana. 2012. Price Earnings Ratio and Stock Return Analysis (Evidence from Liquidity 45 Stocks Listed in Indonesia Stock Exchange). Jurnal Manajemen dan Kewirausahaan 14(1): 7-12.

Geetha, E. dan T. M. Swaaminathan. 2014. A Study on the Factors Influencing Stock Price - A Comparative Study of Automobile and Information Technology Industries Stocks in India. International Journal of Current Research and Academic Review 3(3): 97-109.

Gill, A., N. Biger, dan N. Mathur. 2010. The Relationship between Working Capital Management and Profitability: Evidence from The United States, Business and Economics Journal 10(1): 1-9.

Gottwald, R. 2012. The Use of the P/E Ratio to Stock Valuation. European Grants Projects Journals 2012: 21-24.

Hashemijoo, M., A. Mahdavi-Ardekani, dan N. Younesi. 2012. The Impact of Dividend Policy on Share Price Volatility in the Malaysian Stock Market. Journal of Business Studies Quarterly 4(1): 111-129.

Hoque, J., A. Hossain, dan K. Hossain. 2014. Impact of Capital Structure Policy on Value of the Firm - A Study on Some Selected Corporate Manufacturing Firms under Dhaka Stock Exchange. Ecoforum Journal 3(2): 77-84.

Ibe, S. O. 2013. The Impact of Liquidity Management on the Profitability of Banks in Nigeria. Journal of Finance and Bank Management 1(1): 37-48. 
Jakata, O. dan P. Nyamugure. 2013. The Effects of Dividend Policy on Share Prices: Empirical Evidence from the Zimbabwe Stock Exchange. International Journal of Science and Research (IJSR) 4(10): 674-683.

Joseph, M., M. H. Mbawuni, dan S. G. Nimako. 2016. The Impact of Working Capital Management on Profitability of Petroleum Retail Firms: Empirical Evidence from Ghana. International Journal of Economics and Finance 8(6): 49-62.

Karaduman, H. A., H. E. Akbas, A. O. Caliskan, dan S. Durer. 2011. The Relationship between Working Capital Management and Profitability: Evidence from an Emerging Market. International Research Journal of Finance and Economics 62: 61-67.

Keown, A. J., J. D. Martin, J. W. Petty, dan D. F. Scott. 2003. Foundations of Finance. 4th Edition. Pearson Education. New Jersey.

Khan, R. A. dan M. Ali. 2016. Impact of Liquidity on Profitability of Commercial Banks in Pakistan: an Analysis on Banking Sector in Pakistan. Global Journal of Management and Business Research: Finance 16(1): 53-60.

Khan, S. U., S. M. A. Shah, dan S. T. Hijazi. 2005. Impact of Working Capital Management on the Profitability of Firms: Case of Listed Pakistani Companies. Journal of Social Sciences \& Humanities XIII (2): 41-50.

Khotimah, K. dan I. Murtaqi. 2015. The Fundamental Analysis of Indonesian Stock Return (Case Study: Listed Public Companies in Sub-Sector Food and Beverage for the Period 2003-2012). Journal of Business and Management 4(1): 95-104.

Koumanakos, D. P. 2008. The Effect of Inventory Management on Firm Performance. International Journal of Productivity and Performance Management 57(5): 335-369.

Lazaridis, I. dan D. Tryfonidis. 2006. The Relationship between Working Capital Management and Profitability of Listed Companies in the Athens Stock
Exchange. Journal of Financial Management and Anlysis 19(1).

Luo, M. M., J. J. Lee, dan Y. Hwang. 2009. Cash Conversion Cycle, Firm Performance and Stock Value. http://www 90. homepage.villanova.edu/michael.Pagano ML_CCC_20090420.pdf.

Lyroudi, K. dan J. Lazaridis. 2000. The Cash Conversion Cycle and Liquidity Analysis of the Food Industry in Greece. European Financial Management Association 2000 Athens.

Majanga, B. B. 2015. Cash Conversion Cycle and Firm Profitability in Malawi Manufacturing Sector. Journal of Commerce $\mathcal{E}$ Accounting Research 4(3 dan 4).

Majeed, S., M. Makki, S. Saleem, dan T. Aziz. 2013. The Relationship of Cash Coversion Cycle and Profitability of Firms: an Emperical Investigation of Pakistani Firms. Journal of Emerging Issues in Economics, Finance and Banking 1(1): 35-51.

Mansoori, E. dan D. J. Muhammad. 2012. The Effect of Working Capital Management on Firm's Profitability: Evidence from Singapore. Interdisciplinary Journal of Contemporary Reseaqrch in Business 4(5): 472-486.

Mansoori, E. dan D. J. Muhammad. 2012. Determinants of Working Capital Management: Case of Singapore Firms. Research Journal of Finance and Accounting 3(11): 15-23.

Martha, I. I. C. dan I. Januarti. 2013. Pengaruh Siklus Konversi Kas terhadap Profitabilitas Perusahaan Manufaktur di Bursa Efek Indonesia Tahun 2008-2011. Diponegoro Journal of Accounting 2(2): 111.

Matthew, O. M., Enekwe, C. Innocent, dan M. Anyanwaokoro. 2014. Effect of Dividend Payment on the Market Price of Shares: a Study of Quoted Firms in Nigeria. IOSR Journal of Economics and Finance (IOSR-JEF) 5(4): 49-62.

Miller, M. H. dan F. Modigliani. 1961. Dividend Policy, Growth and The Valuation Of Shares. The Journal of Business 34(4): 411- 433. 
Mousa, S. N. 2015. The Effect of Financial Statement Disclosure on Stock Prices on Industrial Shareholding Companies. European Journal of Business and Social Sciences 4(07): 13-20.

Nijam, H. M. 2016. Cash Conversion Cycle, Its Properties and Profitability: Evidence from Listed Hotel Companies in Sri Lanka. Research Journal of Finance and Accounting 7(1): 23-32.

Nobanee, H., M. Abdullatif, dan M. Al Hajjar. 2011. Cash Conversion Cycle and Firm's Performance of Japanese Firms. Asian Review of Accounting 19(2): 147-156.

Ohlson, J. dan Z. Gao. 2006. Earnings, Earnings Growth and Value. Hanover:Now Publisher Inc.

Ozlen, S. 2014. The Effect of Company Fundamentals on Stock Values. European Researcher 71(3 -2): 595-602.

Padachi, K. 2006. Trends in Working Capital Management and its Impact on Firms' Performance: an Analysis of Mauritian Small Manufacturing Firms. International Review of Business Research Papers 2(2): 45-58.

Panigrahi, A. K. 2013. Cash Conversion Cycle and Firms' Profitability-A Study of Cement Manufacturing Companies of India. International Journal of Current Research 5(06): 1484-1488.

Parveen, S., J. H. Khattak, H. Qayyum, dan I. Afzal. 2014. Impact of Working Capital Management on the Profitability of the Cement Sector of Pakistan. International Journal of Management Sciences and Business Research 3(11): 52-58.

Raheman, A. dan M. Nasr. 2007. Working Capital Management and Profitability Case of Pakistan Firms. International Review of Business Research Papers 3(1): 279-300.

Randall, W. S. dan M. T. Farris. 2009. Supply Chain Financing: Using Cash to Cash Variables to Strengthen the Supply Chain. International Journal of Physical Distribution and Logistics Management 39(8): 669-689.
Richards, V. D. dan E. J. Laughhin. 1980. A Cash Conversion Cycle Approach to Liquidity Analysis. Financial Management 9(1): 32-38.

Ross, S. A., R. Westerfield, dan B. d. Jordan. 2003. Fundamentals of Corporate Finance. $6^{\text {th }}$ Edition. McGraw-Hill Companies. Boston.

Samiloglu, F. dan K. Demirgunes. 2008. The Effect of Working Capital Management on Firm Profitability: Evidence from Turkey. International Journal of Applied Economics and Finance 2(1): 44-50.

Shah, A. 2011. The Corporate Cash Holdings: Determinants and Implications. African Journal of Business Management 5(34): 12939-12950.

Sharma, A. K. dan S. Kumar. 2011. Effect of Working Capital Management on Firm Profitability: Empirical Evidence from India. Global Business Review 12(1): 159173.

Shivakumar dan N. B. Thimmaiah. 2016. Working Capital Management - It's Impact on Liquidity and Profitability - a Study of Coal India LTD. International Journal of Research Granthaalayah 4(12): 178-187.

Sun, L. 2012. Information Content of P/E Ratio, Price-to-book Ratio and Firm Size in Predicting Equity Returns. International Conference on Innovation and Information Management (ICIIM 2012) 36.

Talat, A. dan S. Tahir. 2012. Determinants of Price-Earnings Ratio: the Case of Chemical Sector of Pakistan. International Journal of Academic Research in Business and Social Sciences 2(8): 331-343.

Tauringana, V. dan G. A. Afrifa. 2013. The Relative Importance of Working Capital Management and its Components to SMEs Profitability. Journal of Small Business and Enterprise Development 20(3): 453-469.

Teruel, P. J. G. dan P. M. Solano. 2007. Effects of Working Capital Management on SME Profitability. International Journal of Managerial Finance 3(2): 164-177. 
Umobong, A. A. 2015. Assesing the Impact of Liquidity and Profitability Ratios on Growth of Profits in Pharmaceutical Firms in Nigeria. European Journal of Accounting, Auditing and Finance Research 3(10): 97-114.

Uyar, A. 2009. The Relationship of Cash Conversion Cycle with Firm Size and Profitability: an Empirical Investigation in Turkey. International Research Journal of Finance and Economics 24(2): 186-193.

Vijayakumar, D. A. 2011. Cash Conversion Cycle and Corporate Profitability: an Empirical Enquiry in Indian Automobile Firms. International Journal of Research in Commerce, IT and Management 1(2): 84-91.

Vintila, G. dan E. A. Nenu. 2015. An Analysis of Determinants of Corporate Financial Performance: Evidence from the Bucharest Stock Exchange Listed Companies. International Journal of Economics and Financial Issues 5(3): 732-739.

Vohra, M., H. Raza, M. F. Aslam, dan M. Mubin. 2014. Impact of Working Capital Management on Financial Charges: Empirical Evidence of Manufacturing Industry of Pakistan. Research Journal of Finance and Accounting 5(20): 110-119.
Ware, E. O. 2015. Liquidity Management and Its Effect on Profitability in a Tough Economy: (A Case of Companies Listed on the Ghana Stock Exchange). International Journal of Research in Business Studies and Management 2(11): 1-33.

Wiyono, G. 2011. 3 in One Merancang Penelitian Bisnis: dengan Alat Analisis SPSS 17.0 \& SmartPLS 2.0. UPP STIM YKPN. Yogyakarta.

Wiyono, G. dan D. L. Mumpuni. 2016. Analisis Hubungan Siklus Konversi Kas Dengan Karakter Keuangan Perusahaan Sektor Aneka Industri di Bursa Efek Indonesia. Jurnal Manajemen Fakultas Ekonomi Universitas Sarjanawiyata Tamansiswa 6(2): 12-30.

Wiyono, G. dan H. Kusuma. 2017. Manajemen Keuangan Lanjutan Berbasis Corporate Value Creation. UPP STIM YKPN. Yogyakarta.

Wu, W. T. 2014. The P/E Ratio and Profitability. Journal of Business $\mathcal{E}$ Economics Research 12(1): 68-76.

Yanti, M., U. Salim, M. Sudarma, dan Djumahir. 2012. Determinan Price Earning Ratio dan Stock Return (Studi pada Saham-Saham Syariah di Bursa Efek Indonesia). Jurnal Aplikasi Manajemen 10(2): 273-290. 